American Journal of Economics and Business Administration 1 (2): 133-137, 2009

ISSN 1945-5488

(C) 2009 Science Publications

\title{
New Entry, International Location Patterns and Welfare
}

\author{
Wataru Johdo \\ Department of Economics, Tezukayama University, \\ 7-1-1, Tezukayama, Nara 631-8501, Japan
}

\begin{abstract}
Problem statement: Recently, firms have very actively invested across national borders and the international concentration of industrial activities in emerging countries and developed countries has been rapid. In the new international trade literature, static trade models with firms' location have been widely used, but do not allow for endogenous spatial distribution of firms in the literature. In addition, few studies address the impact of an exogenous increase in the given number of firms on location patterns and welfare in the general equilibrium trade models. Approach: This study constructed a two-country model with monopolistic competition where firms can relocate and pure profits are positive because the total number of firms is fixed. Results: The results indicated that when the given number of firms increases due to new entry, then the number of firms in each country increases at the rate that is equal to the relative size of country and consumers benefit from it. Conclusion: This study simply had analyzed the effects of an exogenous increase in the number of firms. In order to endogenize the number of firms, modeling of R and D investment is necessary. The other weakness of this study is the assumption that a country owns a constant share of the world profit. I expect that the research would become more interesting if the domestic share of the world profit is made endogenous. These extensions remain for future research.
\end{abstract}

Key words: New entry, monopolistic competition, location, two-country model, welfare

\section{INTRODUCTION}

Recently, firms have very actively invested across national borders and the international concentration of industrial activities in emerging countries and developed countries has been rapid. It is, therefore, important to investigate the effects of an increase in the number of firms in an open economy in which the international relocation of firms matters. In the international trade literature, static trade models with firms' location have been widely used in new international trade theories ${ }^{[11]}$. However, few studies address the impact of an exogenous increase in the given number of firms on location patterns and welfare in the general equilibrium trade models that incorporates international relocation of firms.

In order to account for the relationship between the total number of firms and the international distribution of firms, this study modifies the well-known monopolistic competition model of Krugman ${ }^{[11]}$. The modification consist in assuming (i) a different technology: The varieties are produced under constant returns to scale with labor as the only output (no fixed costs) rather than under increasing returns to scale and (ii) that the number of firms (equivalently, the total number of varieties) is exogenously fixed (rather than endogenous) and profit income is distributed according to the parameter. A number of other factors affecting firms' location choices other than product innovation have also been examined in the literature. These include: commodity taxes ${ }^{[6]}$; emission taxes ${ }^{[17]}$; public infrastructure ${ }^{[15]}$; wage taxes ${ }^{[18]}$ and profit tax ${ }^{[9,10]}$. For example, see Ricci $^{[19]}$ for an extensive survey of location theories. The study then analyses an increase in this exogenous number of firms and finds that (i) this additional number will be split in proportion to the labor forces in the two countries and (ii) it boost real per-capita consumption and welfare in both countries.

The study is structured as follows. In "Materials and Methods", we outline the features of the model and describe the steady-state equilibrium. In "Results", we study the impact of an exogenous increase in the given number of firms on these equilibrium values of both countries. In "Discussion" and "Conclusion", we conclude the study with possibilities for future research.

\section{MATERIALS AND METHODS}

We assume a two-country world economy, with a home and a foreign country, in which the overall number of firms is exogenously given, but firms can relocate freely and without any cost between two 
countries. Monopolistically competitive firms exist continuously in the world in the $[0, \mathrm{~m}]$ range, where $\mathrm{m}$ is an exogenous parameter. Firms in the interval $[0, n]$ locate in the home country and the remaining [n, m] firms locate in the foreign country, where $n$ is endogenous. Firms charge mark-up prices based on product differentiation, each producing a unique variety in a single location to serve world demand. Labor is the only input with constant marginal productivity and no fixed costs are required. There is no other activity in either economy than this differentiated goods production. There is free trade between two countries that share identical preferences and have a given size in terms of labor endowment. Departing from the conventional free entry set-up, profits are not wiped out in equilibrium. Instead, the key adjustment is a relocation of firms between the two countries driven by the equilibrium condition that profits are equalized across countries. This analysis further assumes that firms are mobile internationally, but their owners are not. Hence, all profit flows are distributed to the immobile owners according to the respective holding shares. Finally, foreign-country variables are identified with an asterisk.

Households: The size of the world population is normalized to unity. We assume that the shares of households in the home and foreign locations are $\mathrm{s}$ and $\mathrm{s}^{*}$ (三1-s), respectively. Every household supplies one unit of labor to domestic firms at the real domestic wage and receives profits from the internationally mobile firms. The households in each country consume a group of differentiated goods. The maximization problem in the home country is then:

$\max _{\{c j\}} U=c$
s.t. $\theta\left[\int_{0}^{n} \pi_{j} d j+\int_{n}^{m} \pi_{j}^{*} d j\right] / s+w=c$

Where:

$\mathrm{c}=\left(\int_{0}^{\mathrm{m}} \mathrm{c}_{\mathrm{j}}^{(\sigma-1) / \sigma} \mathrm{dj}\right)^{\sigma /(\sigma-1)}, \sigma>1$

In Eq. 2, $\mathrm{c}_{\mathrm{j}}$ is the consumption of product $\mathrm{j}$, which affects the consumption index $c$ and $\sigma$ is the elasticity of substitution between any two varieties. In equation (1), $\theta$ (resp. $1-\theta$ ) denotes the share of the total profit flows of firms that return to home (resp. foreign) agents, $\int_{0}^{\mathrm{n}} \pi_{\mathrm{j}} \mathrm{dj}$ (resp. $\int_{\mathrm{n}}^{\mathrm{m}} \pi_{\mathrm{j}}^{*} \mathrm{dj}$ ) represents the total real profit flows of home- (resp. foreign-) located firms and $\mathrm{W}(\equiv \mathrm{W} / \mathrm{P})$ denotes the real wage rate where $\mathrm{W}$ is the home country's nominal wage rate and $\mathrm{P}$ is the price index of the home country. In other words, $\theta$ denotes the extent to which firms are domestically owned. Huizinga and Nielsen ${ }^{[7,8]}$ and Fuest and Huber ${ }^{[4]}$ studied the feasibility of profit taxation in the presence of foreign ownership of the domestic firm. This study adopts the Dixit and Stiglitz-type consumption index, in which case the consumption-based price indexes are:

$P=P^{*}=\left[\int_{0}^{n} P_{j}^{1-\sigma} d j+\int_{n}^{m} P_{j}^{* 1-\sigma} d j\right]^{1 /(1-\sigma)}$

where, $P_{j}$ is the price of product $\mathrm{j}$. Assuming symmetry between firms, Eq. 3 is reduced to:

$\mathrm{P}=\mathrm{P}^{*}=\left[\mathrm{nP}_{\mathrm{h}}{ }^{1-\sigma}+(\mathrm{m}-\mathrm{n}) \mathrm{P}_{\mathrm{f}}^{* 1-\sigma}\right]^{1 /(1-\sigma)}$

Where:

$\mathrm{P}_{\mathrm{h}}=$ The price of the home good

$\mathrm{P}_{\mathrm{f}}^{*}=$ The price of the foreign good

We define a relative price as $\mathrm{P}_{\mathrm{f}}{ }^{*} / \mathrm{P}_{\mathrm{h}}$. The real prices of the two goods in each country are then respectively $\mathrm{P}_{\mathrm{h}} / \mathrm{P}=\mathrm{P}_{\mathrm{h}} / \mathrm{P}^{*}=\left(\mathrm{P}_{\mathrm{f}}^{*} / \mathrm{P}_{\mathrm{h}}\right)^{-1}\left[\mathrm{n}\left(\mathrm{P}_{\mathrm{f}}^{*} / \mathrm{P}_{\mathrm{h}}\right)^{\sigma-1}+(\mathrm{m}-\mathrm{n})\right]^{1 /(\sigma-1)} \quad$ and $\mathrm{P}_{\mathrm{f}}^{*} / \mathrm{P}^{*}=\mathrm{P}_{\mathrm{f}}^{*} / \mathrm{P}=\left[\mathrm{n}\left(\mathrm{P}_{\mathrm{f}}^{*} / \mathrm{P}_{\mathrm{h}}\right)^{\sigma-1}+(\mathrm{m}-\mathrm{n})\right]^{1 /(\sigma-1)}$ from Eq. 4 .

We take a particular point in time and define a given level of nominal expenditure at that point as $E=\int_{0}^{n} P_{j} c_{j} d j+\int_{n}^{m} P_{j}^{*} c_{j} d j$. Subject to this, the home individual determines $c_{j}$ to maximize (2) in the first stage. From this optimization, we obtain the following demand functions:

$c_{h}=\mathrm{EP}_{\mathrm{h}}{ }^{-\sigma} / \mathrm{P}^{1-\sigma}, \mathrm{h} \in[0, \mathrm{n}], \mathrm{c}_{\mathrm{f}}=\mathrm{EP}_{\mathrm{f}}{ }^{*} / \mathrm{P}^{1-\sigma}, \mathrm{f} \in(\mathrm{n}, \mathrm{m}]$

where, $c_{h}\left(\right.$ resp. $\left.c_{f}\right)$ denotes the demand function for a good produced in the home (resp. foreign) country. Similarly, we obtain the following demand functions for a foreign household:

$\mathrm{c}_{\mathrm{h}}{ }^{*}=\mathrm{E}^{*} \mathrm{P}_{\mathrm{h}}{ }^{-\sigma} / \mathrm{P}^{* 1-\sigma}, \mathrm{h} \in[0, \mathrm{n}], \mathrm{c}_{\mathrm{f}}^{*}=\mathrm{E}^{*} \mathrm{P}_{\mathrm{f}}^{*-\sigma} / \mathrm{P}^{* 1-\sigma}, \mathrm{f} \in(\mathrm{n}, \mathrm{m}]$

where, $E^{*}=\int_{0}^{n} P_{j} c_{j}{ }^{*} d j+\int_{n}^{m} P_{j}^{*} c_{j}^{*} d j$. From (2), (3) and (5), we obtain $\mathrm{c}=\mathrm{e}(\equiv \mathrm{E} / \mathrm{P})$, where e represents the real consumption expenditure.

Firms: Firms produce the differentiated products according to $y_{j}=\ell_{j}$, where $y_{j}$ is the production of home- 
located firm $\mathrm{j}$ and $\ell_{\mathrm{j}}$ represents labor input. Since firm $\mathrm{j}$ hires labor domestically, given $\mathrm{W}, \mathrm{P}$ and $\left(\mathrm{se}^{\mathrm{s}}+\mathrm{s}^{*} \mathrm{e}^{*}\right)$, firm $\mathrm{j}$ faces the following profit maximization problem:

$$
\begin{aligned}
& \max _{\{\mathrm{pj}\}} \mathrm{P}_{\mathrm{j}} \mathrm{y}_{\mathrm{j}}-\mathrm{W} \ell_{\mathrm{j}}, \\
& \text { s.t. } \mathrm{y}_{\mathrm{j}}=\mathrm{sc}_{\mathrm{j}}+\mathrm{s}^{*} \mathrm{c}_{\mathrm{j}}^{*}=\left(\mathrm{P}_{\mathrm{h}} / \mathrm{P}\right)^{-\sigma}\left(\mathrm{se}+\mathrm{s}^{*} \mathrm{e}^{*}\right)
\end{aligned}
$$

where, $\mathrm{sc}_{\mathrm{j}}+\mathrm{s}^{*} \mathrm{c}_{\mathrm{j}}{ }^{*}$ is the total world demand for product j. The price mark-up is chosen according to $P_{j}=(\sigma /(\sigma$ - 1))W. Since $W$ is given, the price mark-up yields $P_{j}=P_{h}, j \in[0, n]$. These relationships imply that each firm supplies the same quantity of goods. Similarly, $P_{j}^{*}=P_{f}^{*}, j \in(n, m]$ holds. Then the real profit flows of the home- and foreign-located firms respectively are:

$\pi_{\mathrm{h}}=(1 / \sigma)\left(\mathrm{P}_{\mathrm{h}} / \mathrm{P}\right)^{1-\sigma}\left(\mathrm{se}_{\mathrm{s}} \mathrm{s}^{*} \mathrm{e}^{*}\right), \pi_{\mathrm{f}}^{*}=(1 / \sigma)\left(\mathrm{P}_{\mathrm{f}}^{*} / \mathrm{P}^{*}\right)^{1-\sigma}\left(\mathrm{se}+\mathrm{s}^{*} \mathrm{e}^{*}\right)$

Full employment of each country requires $n \ell_{j}=s$ and $(\mathrm{m}-\mathrm{n}) \ell_{\mathrm{j}}^{*}=\mathrm{s}^{*}$. In what follows, we assume that the numeraire is the labor of home-located households making $\mathrm{W}=1$.

Equilibrium and product innovation: Henceforth, we denote the steady-state values by using the superscript ss. Equilibrium values are a quadruple $\left(\left(\mathrm{P}_{\mathrm{f}}^{*} / \mathrm{P}_{\mathrm{h}}\right)^{\mathrm{ss}}, \mathrm{n}^{\mathrm{ss}}\right.$, $\left.\mathrm{e}^{\mathrm{ss}}, \mathrm{e}^{\mathrm{ss^{* }}}\right)$. The location-equilibrium condition is:

$$
\pi_{\mathrm{h}}=\pi_{\mathrm{f}}^{*}
$$

This condition enables us to determine the equilibrium spatial distribution of firms across the two countries. In the economic geography literature, Martin and Rogers ${ }^{[15]}$ and Baldwin ${ }^{[1]}$ also require this type of condition to determine the equilibrium distribution of firms across two regions. This is because when real profits are equalized worldwide, no firm has any motivation to relocate another country. On the other hand, in the multinational firm literature, increasing returns to scale is necessary because the overall number of firms is endogenous; for example $\mathrm{e}^{[2,13,14,16]}$. Substituting (8) into this condition yields $\left(\mathrm{P}_{\mathrm{f}}^{*} / \mathrm{P}_{\mathrm{h}}\right)^{\mathrm{ss}}=1$. Moreover, from (4-7), $\mathrm{P}_{\mathrm{h}} / \mathrm{P}=\left(\mathrm{P}_{\mathrm{f}}{ }^{*} / \mathrm{P}_{\mathrm{h}}\right)^{-1}\left[\mathrm{n}\left(\mathrm{P}_{\mathrm{f}}{ }^{*} / \mathrm{P}_{\mathrm{h}}\right)^{\sigma-1}+(\mathrm{m}-\right.$ $\mathrm{n})]^{1 /(\sigma-1)},\left(\mathrm{P}_{\mathrm{f}}^{*} / \mathrm{P}_{\mathrm{h}}\right)^{\mathrm{ss}}=1, \mathrm{n} \ell_{\mathrm{j}}=\mathrm{s}, \mathrm{y}_{\mathrm{j}}=\ell_{\mathrm{j}}$ and $\mathrm{s}+\mathrm{s}^{*}=1$, the equilibrium spatial distribution of firms is $n^{\text {ss }}=m s$. This shows that a higher $\mathrm{s}$ indicates a greater distribution of firms in the home country. This is because the greater the share of labor force in the home location, the larger the labor supply of that country and the lower the home labor wage rate. This raises the profit of home-located firms, which results in firm movement from the foreign to the home country and hence, the number of home-located firms increases. This result is similar to Krugman ${ }^{[1,12]}$, Flam and Helpman ${ }^{[3]}$ and Martin and Rogers ${ }^{[15]}$ findings that the distribution of firms is proportionate to the distribution of workers among regions.

Finally, substituting $\left(\mathrm{P}_{\mathrm{f}}^{*} / \mathrm{P}_{\mathrm{h}}\right)^{\mathrm{ss}}=1$ and $\mathrm{n}^{\mathrm{ss}}=\mathrm{ms}$ into the flow budget equation in (1) and using $\mathrm{P}_{j}=(\sigma /(\sigma-$ 1) $) \mathrm{W}=(\sigma /(\sigma-1))$ and $\mathrm{s}^{*}=1-\mathrm{s}$ yields the following equilibrium levels of consumption for each country, respectively:

$\mathrm{e}^{\mathrm{ss}}=[\theta / \mathrm{s} \sigma+(\sigma-1) / \sigma] \mathrm{m}^{1 /(\sigma-1)}$

and

$\mathrm{e}^{\mathrm{ss} *}=\left[(1-\theta) / \mathrm{s}^{*} \sigma+(\sigma-1) / \sigma\right] \mathrm{m}^{1 /(\sigma-1)}$

The first term in the above equations is the rent income. The second term is the labor income. In particular, when $\theta=1$, which implies that firms are 100 percent domestically owned, the first term in the latter equation disappears.

\section{RESULTS}

Using the above equilibrium values, we investigate the impact on $\mathrm{e}^{\mathrm{ss}}, \mathrm{e}^{\mathrm{ss}}$. and $\mathrm{n}^{\mathrm{ss}}$ of an exogenous increase in the total number of firms (defined by $\mathrm{dm}>0$ ). The effects of such an increase on the above equilibrium values are then:

$\mathrm{de}^{\mathrm{ss}} / \mathrm{dm}=(1 /(\sigma-1))[\theta / \mathrm{s} \sigma+(\sigma-1) / \sigma] \mathrm{m}^{-\sigma /(\sigma-1)}>0$

$\mathrm{de}^{\mathrm{ss} *} / \mathrm{dm}=(1 /(\sigma-1))\left[(1-\theta) / \mathrm{s}^{*} \sigma+(\sigma-1) / \sigma\right] \mathrm{m}^{-\sigma /(\sigma-1)}>0(10)$

$\mathrm{dn}^{\mathrm{ss}} / \mathrm{dm}=\mathrm{s}>0\left(\right.$ or $\left.\mathrm{d}\left(\mathrm{m}-\mathrm{n}^{\mathrm{ss}}\right) / \mathrm{dm}=1-\mathrm{s}>0\right)$

From (9-11), the global innovation increases the consumption of both countries and its effect on the distribution of firms turns out to be proportionate to the share of households in the world population. In particular, Eq. 11 shows an integer problem that if one additional firm enters the market, then fraction $\mathrm{s}$ of a firm will relocate to the home country and fraction 1-s will relocate to the foreign country.

We now consider the impact of the exogenous increase in the total number of firms on the welfare of both countries. From (1), $\mathrm{U}$ and $\mathrm{U}^{*}$ are increasing functions of $\mathrm{e}^{\mathrm{ss}}$ and $\mathrm{e}^{\mathrm{ss}}$, respectively. Hence, the utility 
effects of an increase in the total number of firms for both residents are:

$$
\mathrm{dU} / \mathrm{dm}>0, \mathrm{dU}^{*} / \mathrm{dm}>0
$$

These results show that an increase in the total number of firms raises the utility of both home and foreign agents. The above results can be intuitively explained as follows. Given the Dixit-Stiglitz utility function, an increase in the total number of varieties raises the efficiency of consumers' utility and therefore decreases the price index in the home and foreign country and increases the real value of the wage rates of both countries. In addition, given the excess profits of firms, the increase in the total number of varieties raises the real profits of firms and therefore increases the rent incomes. Thus, an increase in the total number of varieties leads to an increase in the real value of total income in the home and foreign country, thereby increasing the utility of both home and foreign agents.

\section{DISCUSSION}

This study simply has analyzed the effects of an exogenous increase in the number of firms. In order to endogenize the number of firms, modeling of $\mathrm{R}$ and $\mathrm{D}$ investment is necessary as in Flam and Helpman ${ }^{[3]}$ or in the endogenous growth literature ${ }^{[5]}$. The other weakness of this study is the assumption that a country owns a constant share of the world profit. I expect that the research would become more interesting if the domestic share of the world profit is made endogenous. These extensions remain for future research.

\section{CONCLUSION}

This study has used a variation of the monopolistic model by Krugman ${ }^{[11]}$ without trade costs to study the effects of an exogenous entry by firms on the international distribution of firms and welfare in each country. We found that the addition of new firms to a previously fixed number of firms leads to increases in the total number of firms in each country, with the rate of entry into these countries equal to their relative size and increases consumer utility.

\section{ACKNOWLEDGEMENT}

The researcher is grateful to have received financial support from Tezukayama University.

\section{REFERENCES}

1. Baldwin, R.E., 1999. Agglomeration and endogenous capital. Eur. Econ. Rev., 43: 253-280. DOI: 10.1016/S0014-2921(98)00067-1

2. Ethier, W.J. and J.R. Marukusen, 1996. Multinational firms, technology diffusion and trade. J. Int. Econ., 41: 1-28. DOI: 10.1016/00221996(95)01411-X

3. Flam, H. and E. Helpman, 1987. Vertical product differentiation and north-south trade. Am. Econ. Rev., $\quad 77$ : 810-822. http://www.jstor.org/pss/1810210

4. Fuest, C. and B. Huber, 2002. Why capital income taxes survive in open economies: The role of multinational firms. Int. Tax Public Finance, 9: 567-589. DOI: 10.1023/A:1020969604309

5. Grossman, G. and E. Helpman, 1991. Innovation and Growth in the Global Economy. MIT Press, Cambridge, ISBN: 0262071363.

6. Haufler, A. and M. Pfluger, 2004. International commodity taxation under monopolistic competition. J. Public Econ. Theor., 6: 445-470. DOI: $10.1111 /$ j.1467-9779.2004.00174.x

7. Huizinga, H. and S.B. Nielsen, 1997. Capital income and profit taxation with foreign ownership of firms. J. Int. Econ., 42: 149-165. DOI: 10.1016/S0022-1996(96)01449-3

8. Huizinga, H. and S.B. Nielsen, 2002. The coordination of capital income and profit taxation with cross-ownership of firms. Region. Sci. Urban Econ., 32: 1-26. DOI: 10.1016/S01660462(00)00077-6

9. Johdo, W. and K. Hashimoto, 2005. International relocation, the real exchange rate and welfare. $\mathrm{J}$. Econ. Dyn. Control, 29: 1449-1469. DOI: 10.1016/j.jedc.2004.08.007

10. Johdo, W. and K. Hashimoto, 2009. International relocation, the real exchange rate and effective demand. Jap. World Econ., 21: 39-54. DOI: 10.1016/j.japwor.2007.09.001

11. Krugman, P., 1980. Scale economies, product differentiation and the pattern of trade. Am. Econ. Rev., 70: 950-959. http://www.jstor.org/pss/1805774

12. Krugman, P., 1991. Increasing returns and economic geography. J. Political Econ., 99: 483-499. DOI: $10.1086 / 261763$

13. Markusen, J.R. and A.J. Venables, 1998. Multinational firms and the new trade theory. J. Int. Econ., 46: 183-203. DOI: 10.1016/S00221996(97)00052-4 
14. Markusen, J.R. and A.J. Venables, 1999. Foreign direct investment as a catalyst for industrial development. Eur. Econ. Rev., 43: 335-356. DOI: 10.1016/S0014-2921(98)00048-8

15. Martin, P. and C.A. Rogers, 1995. Industrial location and public infrastructure. J. Int. Econ., 39: 335-351. DOI: 10.1016/0022-1996(95)01376-6

16. Norback, P.J., 2001. Multinational firms, technology and location. J. Int. Econ., 54: 449-469. DOI: 10.1016/S0022-1996(00)00092-1

17. Pfluger, M., 2001. Ecological dumping under monopolistic competition. Scand. J. Econ., 103: 689-706. DOI: 10.1111/1467-9442.00266
18. Pfluger, M., 2004. Economic integration, wage policies and social policies. Oxford Econ. Papers, 56: $135-150$.

http://oep.oxfordjournals.org/cgi/content/abstract/5 $6 / 1 / 135$

19. Ricci, L.A., 1999. Economic geography and comparative advantage: Agglomeration versus specialization. Eur. Econ. Rev., 43: 357-377. DOI: 10.1016/S0014-2921(98)00065-8 